It is worthy of remark that the most complete specimens among these rock carvings usually represent the skies at specially characteristic times during the year, such as the equinoxes and the summer solstice. This fact greatly augments their religious significance, and indicates their connection with the annual festivals. Furthermore, these astronomical studies may be explaine by the fact that the stars already served to guide maritime commerce between the South and the North.

We can but wonder whether these carvings were made from memory or from sketches-for we must discard the third hypothesis, that the rock was carved at night from direct observation, since the work would then have teen too difficult. Most of them are no more exact than might expected if they were engraved from memory. However, at least one of them is so remarkably

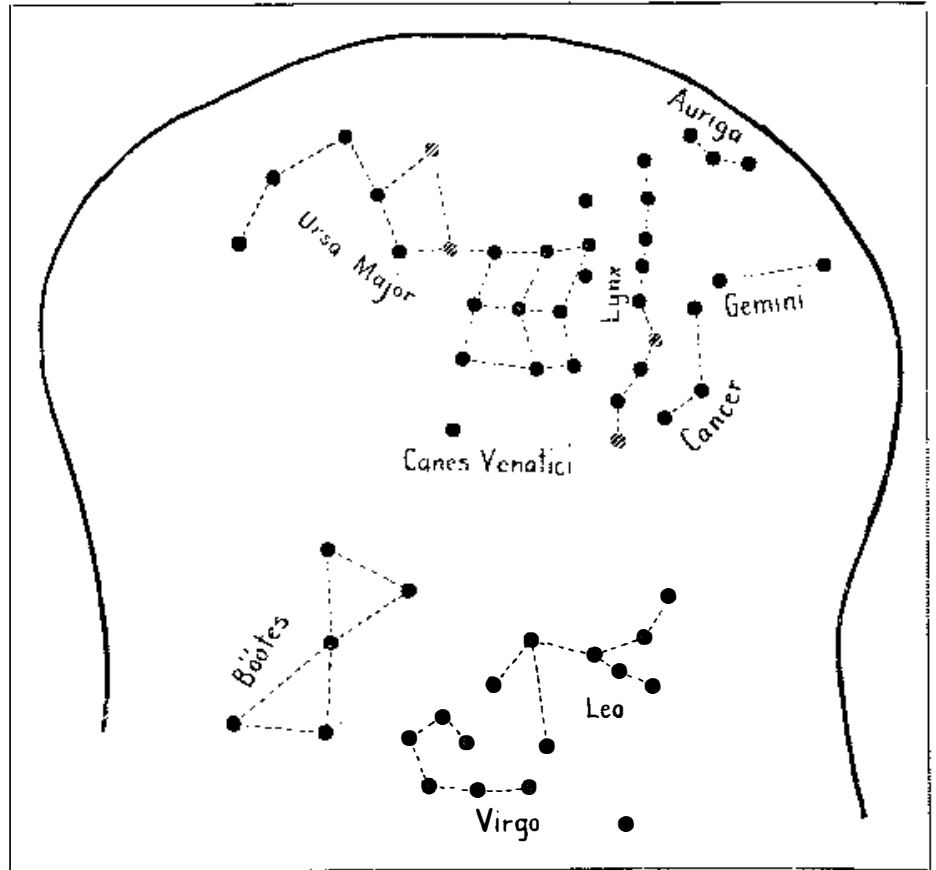

FIG. 7. ROCK CARVING AT DALBY, AFTER GRAVLUND accurate that it is hard to believe that it could have been made without the help of a model. Possibly the artist made a model at night on a piece of wood and transferred the pattern to the stone by daylight.

Skeptical critics will doubtless be found to declare that our theories are based on premises too slight; but certain Scandinavian archaeologists have already made an attempt to prove that even in the Stone Age direct maritime relations existed etween the northern part of Jutland and the distant countries lying toward the south.

The present article does but little more than make a preliminary attack upon this very difficult problem, but we hope that this slight sketch will suffice to attract the attention of scientists competent to undertake the study of this engrossing enigma of the carvings upon the rocks of Scandinavia.

\title{
Tertiary Man in Flanders Fields ${ }^{*}$ \\ Fossil Footprints That Show the Evolution of the Human Foot

\author{
By Professor W. Freudenberg
}

A FEW kilometers to the north of the Episcopal city, St. Niclas, an island of heavy clay arose ages ago from the late Tertiary waters of the North Sea at that time warmed by the Gulf Stream. The Scandinavian Peninsula was still unite with Scotland by a bond of terra firma, forming a barrier against the cold winds and icy ocean currents of the north. The climate along the coasts of that ancient North Sea fed by the English Channel was at that time probably even warmer than it is today in the English Channel Islands and the Isle of Wight. Palms and bamboos spread their fronds luxuriantly upon the mainland through which roamed droves of a three-toed zebra-like horse. On the Isle of Sylt $^{1}$ on the eastern coast of this sea there has likewise been found a tooth of this wild horse, the Hipparion gracile and across the water, on the eastern coast of England, blessed at that time with a subtropical climate, there likewise lived droves of these same ancestors of the zebra as well as antelopes, gazelles and the most various kinds of thick-skinned animals, the rhinoceros and the elephant and even the mastodon. Thus we see that there actually existed an African fauna along the borders of the North Sea before the appearance of those masses of ice from the inland regions to the north, which brought with them their polar tribes of the musk deer, the Arctic fox, the woolly-haired mammoth and the Siberian rhinoceros.

But how long has it been, we may ask, since such a climate prevailed and such animals were seen along our northwest coast? If we reckon "the post-glacial period" with the coast outline and the climate of today at about 25,000 years, then the glacial period itself may be safely assumed

*Translated for the Scientific American Monthly from Die Umschau (Frankfurt A. M.), for Dec. 11, 1920.

${ }^{1}$ This extremely valuable find, which was made in the micaceous clay of the Isle of Sylt, is preserved in the Museum of the Geological Institute at Hamburg. to have lasted for half a million years. But the later Tertiary epoch up to the time that these herds of antelopes and zebras appeare upon the earth, lies fully a million years behind us.

\section{HUMAN BEINGS OF THIS PERIOD}

But now further questions arise in our minds: Did human beings exist at that time, and if so, what did they look like and what did they live upon? Is it not probable rather that they were intermediate forms somewhat like the Pithecanthropus erectus found in an early glacial stratum upon the island of Java? The data obtaine from that remarkable find from the aforesaid little island in the delta of the mouth of the Pliocene Scheldt do not justify us perhaps in answering these questions with a positive affirmation; they are mere sign-posts but none the less worth noting. To begin with, let us inquire how it is possible for us to speak confidently of the existence of an island or a peninsula or even of a zone of shore in those ancient times, in a locality where there is today nothing but a flat and sandy plain. We should not be able to answer these questions without the aid of the spades and the drills of geologists. These men of science are able to recognize when and how the formation occurred of any sort of ground, whether its material be clay or sand or the moraines that mark a glacier's path. The degree of development of those sea mussels found in that sort of clay from the ocean bed gives to the geologist an indication of the time when this deposit occurred, and he may be helped in forming his estimates, moreover, by the fossils of the fishes or the drowned land animals, ${ }^{2}$ which may chance to be found there also. In the case in hand there may have been mud deposited in the neighborhoo of the coast, at a depth of about 100 meters, let us say, and this slime or mud may itself have become firm

2A small marsupial animal has recently been found in the Septarian clay at Antwerp. 
land by reason of a retreat of the sea from the land at that point. The shore thus left dry would be changed in shape and outline at a much later period by the streams and the storms of the land. Thus there was formed a little circle of islands not unlike our Friesian Islands, but on a much smaller scale and with a partial connection of the islands with the solid land, like the islands of the delta of the Rhine. We must next suppose that through a sinking of the coast the sea sturged up upon the land once more, after the ocean had reached its greatest depth. This happened, in fact, at the time when droves of three-toed horses were sweeping across the continent from China to Portugal, to Jutland, and to England, when a continental steppe climate spread over wide areas of the continent of Asia and Europe, accompanied by a similar spread of the fauna proper to such a climate. It was at this time, according to our assumption, that man made his appearance. His ancient tertiary and middle tertiary ancestors had been dwellers in subtropical forests. They belonged to a well-known race of anthropoid apes, we may believe, though this is not the proper place to discuss the mental qualities of those European anthropoids of Middle Tertiary times. Yet we may assume, I think, that matters stood thus with our corporeal ancestors if we admit that the intellectual life of man must be regarded as something of a peculiar nature and slow in development in relation to the race history of humanity. Let us inquire then as to what hypotheses may be suggested in these matters and what scientific conclusions it is possible to arrive at. As a geologist and a palaeo-biologist I am obliged to believe that these first members of the human race developed under external conditions such as those which have aided in the evolution of the most intellectual races of today. By this I mean that they were plainsmen-dwellers upon the open steppes. Here we have conditions highly favorable to the constant stimulus and consequent development of the functions of the brain of those anthropoidal ancestors of ours-creatures whose structure of body and degree of mentality resembled those of the great anthropoid apes-who had hitherto found their homes amid dense forests or in dark and narrow caves. For on the plains we have the open horizon with its implied demand for that estimation of distances which is a matter of such great importance to wayfarers across deserts or steppes, since an erroneous estimate all too frequently brings starvation in its train; here, too, man is vouchsafed the unhindered observation of the stars. It is evident that the vast sweep of the heavens above and the far-flung line of the horizon below tend to develop in the nomads of the plains and in the sons of the desert that power of measuring and reckoning-of calculation, in short-whose further evolution we observe in the seafarer and in the merchant.

Unsightly enough are the footprints left behind him for our inspection by the Tertiary man at Hol by St. Gilles in Flanders. These consist of impressions of the ball of the foot in which are plainly seen the marks of the papillary ridges and furrows-so clearly marked are these indeed after the lapse of a million years that they might attract not only the investigating eje of a studious anthropologist but that of a modern detective! Even the small toe has left its imprint-only half that of the fourth toe, however, is visible in the impression. This footprint, now hardened into stone, was once impressed in a lump of the tenacious Tertiary clay which formed the aforesaid shore or island and as the foot that made it strode away it was kicked off into the sands of the dunes. When, toward the end of the Tertiary period the Middle Pliocene North Sea flooded the islands of the Scheldt it spread over the clay which composed them the sediment borne in the raging waters. These imprints of human-looking toes hardened into solid stone and as such they remained upon the shore of the steadily southward spreading sea.

What was the creature who left these footmarks doing there? Was he really a man or merely one of a race of anthropoid apes, traces of which have already been found in the older Tertiary strata and which we recognize by their bony remains and their teeth? To begin with, while we may concede that these creatures were quadrupeds they were by no means ape like since the toe prints are all short-for that matter our own babies might be said to be quadrupeds at an early stage of their existence. How skilful the use an infant often makes of the soles of his feet and of his still mobile and unatrophied toes! And does not the fact that France has produced both a painter and a tapestry maker who, lacking hands, accomplished their work with their feet, offer proof enough that our Tertiary ancestors of a million years ago were four-footed creatures?

The anthropoid apes of today, the gibbon, orang-outang, and the chimpanzee with their many species and subspecies (in the case of the gibbon) all have long, climbing toes upon their feet: this is more marked among the apes of the East than among the anthropoid apes of the West, the chimpanzee and the gorilla, which possess the shortest toes by far among all the group of our nearest animal relations. This indicates that the foot is in these creatures not exclusively a climbing organ, but that they use rather the toes of the foot as a highly sensitive lever in order to balance the heavy body when in an upright position, just as human beings do when walking. We may conclude, therefore, that these toes which left their imprint so long ago in the late Tertiary coastal zone of Flanders, were constructed upon the same plan and for the same purpose.

Indicated Size of the Tertiary Man.-It is a striking cir-

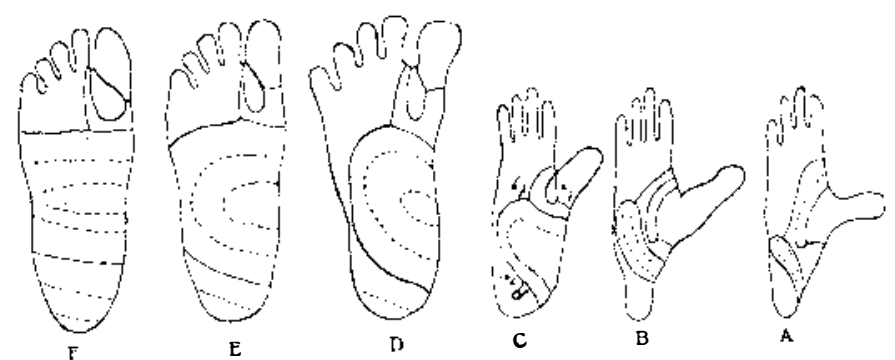

FIG. 1. SERIES OF DIAGRAMS SHOWING THE DEVELOPMENT OF THE SOLE OF THE HUMAN FOOT

$A$ to $C$, the forerunners of mankind; $D$ to $F$, the development of the foot from Tertiary man to the present time.

cumstance that the toes which made these tracks were quite small. They correspond in size to those of a four-year-old boy, hence they must have belonged to a pigmy less than one meter in height. At the same time it is evident that the impression was made by the foot of an adult. A proof of this is found in the imprint made by the ball of the foot. In the young offspring both of human beings and of the anthropoid apes the tactile ridges and furrows upon the soles of the feet and the palms of the hand lie much closer together than in adults of the same race and sex as may be seen in Fig. 1. During the growth of the individual the skin and those small structures upon it which serve the function of touch become expanded. The ball of the foot of this prehistoric Tertiary man, assuming that it belongs to the same species as the aforesaid toes of human appearance, has the furrows of the tactile papillæ so far apart as to make it evident that the impression was made by an adult foot. The curvature of the impression of the ball of the foot, however, indicates plainly that its maker must have been less than one meter tall.

But we cannot avoid the belief that creatures of an anthropoidal nature and walking upright, must have moved about a good deal, even were they not driven by a genuine wanderlust, especially if we assume that the reason for the development of a foot so typically human in its aspect is to be attributed to the appearance of a climate like that of the steppes in Europe and Asia north of the Tertiary chain of mountains. The acquisition of such a foot could not have taken place amid dense primeval forests where both men and their rela- 
tives, the anthropoid ape, must have remained as they were originally: chiefly tree-dwellers with feet adapte for climbing and with a more or less uncertain gait upon flat ground.

But the footprints of which we speak were found in the vicinity of the late Tertiary seashore. Possibly they were made in the miry ground of the delta at the mouth of the primeval Tertiary Scheldt, which appears especially probable in the case of the print made by the ball of the foot. The impress of the toes, which was found in the sandstone and was made therefore upon a sandy ground, was probably made also in the neighborhood of the sea-perhaps, likewise, on the shore itself-and then covered wiht a fresh layer of sand, which would account for the sharpness of its outline. Upon the under side of this imprint of the toes there is to be seen the impression made by a shell fish which suggests that this primeval man may have sought the shore to hunt for missels.

A few kilometers to the east of the clay pit at Hol (St. Gilles), where the writer of these lines with the aid of some Belgian workmen, made the aforesaid find in the Tertiary sand-covering of the clay pit of a brickyard during the war, an excavation was made by the same workmen to the north of the locality of Vracene which afforded welcome support to the aforesaid hypothesis. We were digging in the same late Tertiary covering of sand as at Hol (where our discoveries were principally made), but in this new location the sea sand lay in a much thicker stratum above the clay, for the reason that we had left the vicinity of that ancient island of clay, and proceeded in the direction of Antwerp, where a much deeper sea prevailed during the geological epoch in question. This is evident in fact from the remarkable depth of the strata of sand in which the docks of Antwerp have been constructed. But in this locality, also, Septarian clay forms the foundation of the strata of sand. An enormous quantity of whale skeletons came to light during the building of the old harbors and among them were found also a number of the finely notched saw-like teeth, as big as a man's hand, of a giant shark whose present relatives (quite a bit smaller of size), make their home in tropical waters. Such teeth as these, with edges sharp as knives, were also found in our own excavations, especially at the point where the footprint was found, and these offer quite special proof of our thesis, since to all appearance these teeth were eagerly sought for by Tertiary man as valuable work tools, so that when these primitive creatures wandere shoreward they kept their eyes open, not only on the look-out for mussels to supplement their food and for bones and nints for utensils, but also for the huge shark teeth described above to assist them in opening the tightly-closed shells of the still living mussels which were part of their treasure trove. At first thought this may sound like a rather fantastic idea, but it is supported by the fact that one of our finds at Vracene was a number of mussels in the uppermost layer of the Tertiary mussel sand which had obviously been opene artificially by a sharp stroke or cut. As a proof that these mussel shells were really of tertiary origin and belonged, therefore, to the preglacial era we may note that those mussels which exhibited an incision of artificial origin (obviously intended to cut off the front muscle employed in closing the shell) belong to a species which is not only entirely extinct today but is lacking even in the diluvial strata of the glacial era. They are, in fact, the Cyprina tunida, a relative of the Iceland mussel.

Are we not, therefore, quite justified in regarding these ancient Netherlanders of those primeval times as true epicures, knowing how to appreciate oysters, as is proved by the numerous broken shells found at Vracene? We can, in fact, speak of piles of mussel shells, heaped up obviously by creatures more or less human in character along the aforetime borders of the Flemish North Sea, which today lie many kilometers inland by reason of the subsequent raising of the coast line during the glacial period. For there were also times during the glacial period in which the North Sea flowed farther to the south than is the case today.
Less illuminating as to their object than the incisions upon the two-shelled mussels are the regular curving strokes made upon the thick skull bones of an extinct species of whale. The idea suggests itself that some flexible material such as, perhaps, the skin of a seal, a walrus or sea cow (which at that time had not retreate toward the south) may have been rubbed against these grooved skull bones in order to rub off the fatty tissue clinging to it. This kind of manipulation would, of course, indicate quite a considerable degree of intelligence and skill. Often, too, they may have employed exceedingly sharp fragments of flint which are found among the deposit along tertiary shores. However, we cannot be quite sure of the artificial origin of these splinters of flint. All the more important is the discovery of what are undoubtedly artificially shaped flinty stones of the same period, i.e., in the upper tertiary strata in the vicinity of Aurillac in southern France, by Professor Verworn of Bonn. We may assume, therefore, that tertiary man was clever enough successfully to shape tools from flint. This alone indicates a great step in advance over apes.

An Engraved Mussel Shell.-In the English Red Crag which is likewise a late tertiary shore formation, there has: been found an engraved mussel shell upon whose convex side a human face has been crudely carved. It looks, to be sure, like the scratching of a child and yet this reddish stone still firmly retains the lines graved by this first exponent of the plastic art. There is a small hole bore through the "backbone" of the shell, so that the mussel could be worn as a pendant. To a period somewhat later at about the turning point between the tertiary and the diluvian, we find the most ancient man upon English soil in the form of the skull and the lower jaw of the Eoanthropus. The former exhibits external features more human in character but it contained the most primitive brain ever found in the skull of man. The lower jaw is quite ape-like with a shovel-shaped projecting snout. So different is its aspect from everything that we call human today, that it was at first thought by geologists to belong to a chimpanzee.

However, even today there are found in England men with lower jaws of a low degree of development-an inheritance. perhaps, from these primitive men. On the other hand the most ancient midlle-European ever found, the Homo Heidelbergensis, exhibits purely human features in the form of the teeth together with a very remarkable, but not especially apelike lower jaw. The third example of human remains likewise in the ancient quarternary was made in Java. This is the celebrate Pithecanthropus erectus whose upright carriage indicate by the thigh bone is combined with a very ape-like brain pan. Thus we have to discriminate between three different species of primeval man at about the turning point of the tertiary period. It seems probable that in other parts of the world, at about the same period of time there must have existed other markedly different forms of primeval man.

Instead of coming nearer to a common origin of man, as the ancient lore of church and school teaches us, and as even universities have been accustomed to hold, the farther we trace man back to a possible origin the more different in nature are the various races of man. Indeed there are absolutely definite points of resemblance between certain races and the anthropoid ape. According to our hypothesis we must regard human beings as correlate forms of evolution, as adaptations to a certain form of environment. The upright gait and the nobly arched skull must in the final analysis be regarde not as a common inheritance, but as a highly complex adaptation to the steppes or plains. To begin with. naturally, the region of the Asiatic steppes furnishes the original home of the modern sort of mankind, but it is also true that that realm of Europe which was transformed from a primeval forest into a great bare plain or steppe-particularly in the vicinity of the mountains with their numberless stimuli for the development of the human foot, must have been centers of creation for humankind. 